\title{
ANALISIS PENGARUH PERTUMBUHAN EKONOMI DAN INFLASI TERHADAP HARGA SAHAM PADA PERUSAHAAN REAL ESTATE DAN PROPERTY YANG TERDAFTAR DI BURSA EFEK INDONESIA PERIODE 2011 - 2015
}

\author{
Masta Sembiring \\ Dosen Fakultas Ekonomi dan Bisnis Universitas Muhammadiyah Sumatera Utara \\ Email : azthabiring80@gmail.com
}

\begin{abstract}
ABSTRAK
Penelitian ini bertujuan untuk mengetahui (1) pengaruh pertumbuhan ekonomi dan inflasi terhadap indeks harga saham sektor properti dan real estate, (2pertumbuhan ekonomi terhadap indeks harga saham sektor properti dan real estate, dan (3) inflasi terhadap indeks harga saham sektor properti dan real estate yang tercatat di Bursa Efek Indonesia tahun 2011-2015. Penelitian ini dilaksanakan di Bursa Efek Indonesia dengan menggunakan desain kuantitatif kausal. Subjek dalam penelitian ini adalah seluruh perusahaan yang termasuk dalam industri properti dan real estate yang terdaftar pada Bursa Efek Indonesia dan objeknya adalah pertumbuhan ekonomi, inflasi, dan indeks harga saham sektor properti dan real estate. Data yang diperlukan dalam penelitian ini adalah data kuantitatif yang dikumpulkan dengan pencatatan dokumen dari Bank Indonesia, Badan Pusat Statistik dan Bursa Efek Indonesia yang dianalisis dengan analisis regresi linier berganda. Hasil dari analisis regresi linier berganda menunjukan bahwa (1) ada pengaruh secara simultan yang signifikan dari pertumbuhan ekonomi dan inflasi terhadap indeks harga saham sektor properti dan real estate, (2) tidak ada pengaruh secara parsial dari pertumbuhan ekonomi terhadap indeks harga saham sektor properti dan real estate, dan (3) ada pengaruh secara parsial yang signifikan dari inflasi terhadap indeks harga saham sektor properti dan real estate yang tercatat di Bursa Efek Indonesia tahun 2011-2015.
\end{abstract}

Kata kunci: pertumbuhan ekonomi, inflasi, indeks harga saham sektor properti dan real estate

\section{PENDAHULUAN}

Krisis ekonomi yang melanda Amerika Serikat terjadi akibat macetnya kredit properti (subprime mortgage), yaitu sejenis kredit kepemilikan rumah (KPR) di Indonesia. Efek beruntun dari kredit perumahan itu membuat beberapa perusahaan keuangan besar di Amerika dan juga perusahaan lain di seluruh dunia bangkrut (Adiwarman, 2008). Ada duapengaruh langsung krisis finansial global terhadap perekonomian di negara Indonesia.Pertama pengaruh terhadap keadaan indeks bursa saham Indonesia. Kepemilikan asing, yang masih mendominasi dengan porsi $66 \%$ kepemilikan saham di BEI, mengakibatkan bursa saham rentan terhadap keadaan finansial global karena kemampuan finansial para pemilik modal tersebut (Tempo Interaktif, 2008). Kedua, dibidang ekspor impor, Amerika Serikat merupakan negara tujuan ekspor nomor dua setelah Jepang dengan porsi 20\% 30\% dari total ekspor (Depperin, 2008). Dengan menurunnya kinerja ekonomi Amerika Serikat secara langsung akan mempengaruhi ekspor impor negara Indonesia juga. Pengaruh lain krisis finansial global terhadap ekonomi makro adalah dari sisi tingkat suku bunga. Dengan 
naiknya kurs dollar, suku bunga akan naik karena Bank Indonesia akan menahan rupiah sehingga akibatnya inflasi akan meningkat. Kedua, gabungan antara pengaruh kurs dollar tinggi dan suku bunga yang tinggi akan berdampak pada sektor investasi dan sektor riil, dimana investasi di sektor riil seperti properti dan usaha kecil dan menengah (UKM) akan terganggu. Perusahaan real estate dan property merupakan unit bisnis yang bergerak dalam bidang pembangunan rumah dan pemukiman dan juga tergabung dalam usaha konstruksi bangunan yang bahan utamanya adalah bahan bangunan. Tingginya inflasi akan mendorong harga bahan bangunan menjadi semakin mahal, menyebabkan tingginya biaya produksi yang harus di tanggung oleh perusahaan. Seperti diketahui bahwa inflasi dapat menaikkan biaya produksi dan dapat membuat daya beli masyarakat akan menjadi menurun. Penurunan daya beli dan biaya produksi yang tinggi secara tidak langsung akan mempengaruhi kondisi pasar modal. Investor tidak akan tertarik untuk menanamkan modalnya dan permintaan terhadap saham khususnya saham real estate dan property menjadi turun. Penurunan permintaan akan menyebabkan harga saham ikut mengalami penurunan. Jadi pertumbuhan investasi di suatu negara dipengaruhi oleh pertumbuhan ekonomi negara tersebut. Semakin baik tingkat perekonomian suatu negara maka semakin baik pula tingkat pendapatan masyarakat. Adanya peningkatan pendapatan diharapkan semakin banyak orang yang memiliki kelebihan dana dan dana tersebut dapat dimanfaatkan untuk disimpan dalam bentuk tabungan atau diinvestasikan dalam bentuk surat-surat berharga yang diperdagangkan di pasar modal. Harga saham selain dipengaruhi oleh faktor pasar, juga dapat di pengaruhi oleh faktor makro lainnya seperti inflasi, jumlah uang yang beredar, kurs valuta asing, dan tingkat suku bunga. Penelitian ini dilakukan dengan anggapan bahwa variabelvariabel dalam faktor-faktor ekonomi pertumbuhan ekonomi dan inflasi merupakan variabel yang berpengaruh secara sistematik sebagai dasar pencapaian laba dengan dasar perubahan perekonomian berpengaruh dengan pola serupa terhadap saham perusahaan, khususnya variabel makro yaitu pertumbuhan ekonomi dan inflasi. Berdasarkan latar belakang masalah yang telah diuraikan, maka rumusan masalah yang dapat dikemukakan sebagai berikut:

1. Apakah pertumbuhan ekonomi dan inflasi secara simultan mempunyai pengaruh terhadap harga saham pada perusahaan properti yang tercatat di Bursa Efek Indonesia?

2. Apakah pertumbuhan ekonomi dan inflasi secara parsial mempunyai pengaruh terhadap harga saham pada perusahaan properti yang tercatat di Bursa Efek Indonesia?

3. Manakah yang mempunyai pengaruh dominan di antara pertumbuhan ekonomi dan inflasi terhadap harga saham pada perusahaan properti yang tercatat di Bursa Efek Indonesia?

\section{TINJAUAN TEORITIS}

\section{Faktor - Faktor yang Menentukan Pertumbuhan Ekonomi}

Proses pertumbuhan ekonomi dipengaruhi oleh dua macam faktor yang terdiri dari faktor ekonomi dan faktor non ekonomi. Faktor ekonomi mencakup sumber alam atau tanah, akumulasi modal, organisasi, dan kemajuan tekhnologi, sedangkan faktor non ekonomi seperti sumberdaya manusia dan faktor politik dan administratif.

\section{Inflasi}

Inflasi merupakan kenaikan harga barang-barang secara umum yang disebabkan oleh 
turunnya nilai mata uang pada suatu periode tertentu. Nopirin (2009:25) mendefinisikan inflasi sebagai proses kenaikan harga-harga umum barang-barang secara terus-menerus. Menurut Nopirin (2009:27) terdapat berbagai jenis Inflasi, antara lain:

1. Jenis inflasi menurut sifatnya

a. Creeping inflation adalah inflasi yang ditandai dengan kenaikan harga yang lambat, dengan persentase yang kecil serta dalam jangka yang relatif lama. Laju inflasi rendah (kurang dari 10\% pertahun)

b. Galloping inflation adalah inflasi yang ditandai dengan kenaikan harga yang cukup besar (biasanya double digit atau bahkan triple digit) dan kadang kala berjalan dalam waktu yang relatif pendek serta mempunyai sifat akselerasi. Artinya harga-harga minggu/bulan ini lebih tinggi dari minggu/bulan lalu dan seterusnya.

c. Hiper inflation merupakan inflasi yang paling parah akibatnya. Harga-harga naik sampai 5 atau 6 kali. Masyarakat tidak lagi berkeinginan untuk menyimpan uang.

Nilai uang merosot dengan tajam, perputaran uang makin cepat, harga naik secara akselerasi. Biasanya keadaan ini timbul apabila pemerintah mengalami defisit anggaran belanja (misalnya ditimbulkan oleh adanya perang) yang dibelanjai/ditutup dengan mencetak uang.

2. Jenis inflasi menurut sebabnya

a. Demand full inflation adalah inflasi yang bermula dari adanya kenaikan permintaan total (agregat demand), sedangkan produksi telah berada pada keadaan kesempatan kerja penuh atau hampir mendekati kesempatan kerja penuh.

b. Cost-pushi inflation adalah inflasi yang ditandai dengan kenaikan harga serta turunnya produksi.

\section{Efek Inflasi}

Inflasi dapat mempengaruhi distribusi pendapatan alokasi faktor-faktor serta produksi nasional (Nopirin, 2009:32). Efek terhadap produksi pendapatan disebut Equity Effect, sedangkan efek terhadap faktor produksi dan produksi nasional masingmasing disebutdengan Efficiency dan Output Effect.

1. Efek terhadap Pendapatan (Equity Effect)

Sifatnya tidak merata ada yang dirugikan tetapi ada pula yang merasa diuntungkan dengan adanya inflasi. Pihak-pihak yang mendapat keuntungan dari inflasi adalah pihakpihakyang memperoleh kenaikan pendapatan dengan prosentase yang lebih besar dari laju inflasi tersebut. Seorang yang berpenghasilan tetap akan dirugikan dengan adanya inflasi. Dengan demikian inflasi dapat menyebabkan terjadinya perubahan besar dalam pola pembagian pendapatan dan kekayaan masyarakat umum. Inflasi ini seolaholah merupakan pajak bagi beberapa pihak dan merupakan subsidi bagi orang lain.

2. Efek Terhadap Efisiensi (Efficiency Effect)

Inflasi dapat pula mengubah pola alokasi faktor-faktor produksi. Perubahan ini dapat terjadi melalui kenaikan permintaan akan berbagai macam barang tertentu yang mengalami kenaikan lebih besar daripada barang lain, yang kemudian dapat mendorong kenaikan produksi barang tersebut. Kenaikan barang ini pada gilirannya akan mengubah pola alokasi faktor produksi yang telah ada. Tidak ada pendapat yang menjamin bahwa alokasi faktor produksi tersebut lebih efisien pada keadaan tidak terdapat inflasi. Nmaun 
kebanyakan pendapat tersebut menyebutkan bahwa inflasi dapat menyebabkan alokasi factor produksi dapat berubah menjadi tidak efisien.

3. Efek Terhadap Output ( Output Effect)

Dalam analisa kedua efek tersebut di atas terdapat suatu anggapan bahwa output dalam keadaan tetap. Inflasi mengkin dapat mengakibatkan kenaikan produksi. Karena dalam keadaan adanya inflasi, biasanya kenaikan barang mendahului kenaikan upah sehingga pengusaha mendapatkan keuntungan yang bertambah. Kenaikan keuntungan ini akan mendorong kenaikan produksi. Namun apabila laju inflasi tersebut cukup tinggi (hyperinflation) akan mempunyai akibat yang sebaliknya yaitu penurunan output.

Intensitas efek inflasi ini berbeda-beda, tergantung kepada apakah inflasi tersebut dibarengi dengan kenaikan produksi dan employment atau tidak. Apabila produksi barangikut naik, maka kenaikan produksi sedikit banyak dapat memperlambat laju inflasi. Tetapi apabila ekonomi mendekati kesempatan kerja penuh (full employment) sering disebut inflasi umum (pure inflation).

\section{Cara Mencegah Inflasi}

Cara-cara mencegah inflasi menurut Nopirin (2009:34) dapat menggunakan beberapa kebijakan, diantaranya:

1. Kebijakan moneter

Sasaran kebijakan moneter dicapai melalui pengaturan jumlah uang beredar. Salahsatu komponen uang beredar adalah uang giral (demand deposit). Bank sentral dapat mengatur uang giral melalui penetapan cadangan minimum. Untuk menekan laju inflasi cadangan minimum ini dinaikkan sehingga jumlah uang menjadi lebih kecil. Disamping cara ini bank sentral juga dapat menggunakan tingkat diskonto (discount rate). Discount rate adalah tingkat diskonto untuk pinjaman yang diberikan oleh bank sentral pada bank umum. Apabila tingkat diskonto ini dinaikkan (oleh bank sentral), maka gairah bank umum untuk meminjam makin kecil sehingga cadangan yang ada pada bank sentral juga mengecil. Akibatnya kemampuan bank umum memberikan pinjaman pada masyarakat makin kecil sehingga jumlah uang beredar turun dan inflasi dapat dicegah. Politik pasar terbuka juga dapat mencegah terjadi inflasi. Politik pasar terbuka adalah suatu kebijaksanaan dari Bank Sentral untuk menjual surat-surat berharga seperti obligasi Negara terhadap masyarakat. Maka ini berakibat berkurangnya uang beredar dari tangan masyarakat, dan menyebabkan permintaan terhadap barang berkurang serta barangbarang dapat dijual seluruhnya apabila harga diturunkan. Dengan demikian inflasi dapat dikurangi tekanannya.

2. Kebijakan fiskal

Kebijakan fiskal menyangkut peraturan tentang pengeluaran pemerintah serta perpajakan yang secara langsung dapat mempengaruhi permintaan total dan dengan demikian akan mempengaruhi harga. Inflasi dapat dicegah melalui penurunan pengeluaran pemerintah serta kenaikan pajak akan dapat mengurangi permintaan total, sehingga inflasi dapat dicegah.

3. Kebijakan yang berkaitan dengan output

Kenaikan output dapat memperkecil laju inflasi. Kenaikan jumlah output dini dapat dicapai misalnya dengan kebijakan penurunan bea masuk sehingga impor barang cenderung meningkat. Bertambahnya jumlah barang di dalam negeri cenderung menurunkan harga.

4. Kebijakan penentuan harga dan indexing

Kebijakan ini dilakukan dengan penentuan ceiling harga serta mendasarkan pada 
indek harga tertentu untuk gaji ataupun upah (dengan demikian gaji/upah secara riil tetap). Kalau indeks harga naik, maka gaji/upah juga dinaikkan Tingkat inflasi domestik akan selalu berubah menyesuaikan diri dengan tingkat inflasi dunia. Tetapi hal itu tidak berarti bahwa perubahan stok uang domestik tidak berpengaruh pada harga-harga domestik. Ekspansi uang dan kredit yang berlebihan tetap akan mengakibatkan inflasi domestik yang untuk sementara waktu melebihi tingkat inflasi dunia. Tetapi situasi itu tidak bisa berlangsung dalam jangka panjang, karena kelebihan penciptaan uang akan menciptakan impor sehingga menurunkan cadangan internasional dan pada akhirnya ketidakmampuan untuk menjaga kurs tetap atau devaluasi. (Hakim, 2010:372). Di negara berkembang dengan sistem kurs tetap, kebijakan yang harus diadopsi untuk menghindari tingkat inflasi karena pengaruh inflasi dunia adalah lebijakan fiskal bukan kebijakan moneter. Jika defisit anggaran tidak terjaga instrumen kebijakan moneter yang paling tepat sekalipun akan sulit untuk menjaga inflasi, devaluasi atau keduanya.

\section{Saham dan Harga Saham}

Saham adalah tanda penyertaan modal pada perseroan terbatas seperti yang telah diketahui bahwa tujuan pemodal membeli saham untuk memperoleh penghasilan dari saham tersebut. Masyarakat pemodal itu dikategorikan sebagai investor dan speculator. Investor disini adalah masyarakat yang membeli saham untuk memiliki perusahaan dengan harapan mendapatkan deviden dan capital gain dalam jangka panjang, sedangkan spekulator adalah masyarakat yang membeli saham untuk segera dijual kembali bila situasi kurs dianggap paling menguntungkan seperti yang telah diketahui bahwa saham memberikan dua macam penghasilan yaitu deviden dan capital gain. Ada berbagai definisi saham yang telah dikemukakan oleh para ahli maupun berbagai buku-buku teks, antara lain:

Menurut Darmadji dan Fakhruddin (2006:5) yang dimaksud dengan saham adalah: "Sebagai tanda penyertaan atau pemilikan seseorang atau badan dalam suatu perusahaan atau perseorangan terbatas. Wujud saham adalah selembar kertas yang menerangkan bahwa pemilik kertas tersebut adalah pemilik perusahaan yang menerbitkan surat berharga tersebut. Porsi kepemilikan ditentukan oleh seberapa besar penyertaan yang ditanamkan di perusahaan tersebut."

\section{Jenis-Jenis Saham.}

Menurut Darmadji dan Fakhruddin (2006:6-7) jenis-jenis saham diklasifikasikan sebagai berikut:

1. Jenis saham dilihat dari segi kemampuan dalam hak tagih atau klaim dibedakan menjadi:

a. Saham biasa: saham yang menampatkan pemiliknya paling junior terhadap pembagian dividen, hak atas kekayaan perusahaan apabila perusahaan tersebut dilikuidasi.

b. Saham preferen: saham yang memiliki karakteristik gabungan antara obligasi dan saham biasa, karena bisa menghasilkan pendapatan tetap (seperti bunga obligasi), tetapi juga bisa tidak mendatangkan hasil seperti yang dikehendaki investor. Saham preferen dipandang sebagai surat berharga dengan pendapatan tetap. 


\section{Harga Saham}

1. Harga Nominal

Harga nominal merupakan nilai yang tertera pada lembaran surat saham yang besarnya ditentukan dalam Anggaran Dasar Perusahaan. Harga nominal sebagian besar merupakan harga dugaan yang rendah, yang secara arbitrer dikenakan atas saham perusahaan. Harga ini berguna untuk menentukan harga "saham biasa yang dikeluarkan". Besarnya harga nominal memberikan arti penting saham karena dividen minimal biasanya ditetapkan berdasarkan nilai nominal.

2. Harga Perdana

Harga ini merupakan harga yang dicatat pada bursa efek. Harga saham pada pasar perdana biasanya ditetapkan oleh penjamin emisi (underwriter) dan emiten. Dengan demikian, akan diketahui berapa harga saham emiten itu akan dijual kepada masyarakat biasanya untuk menentukan harga perdana.

3. Harga Pasar

Harga ini merupakan harga yang ditetapkan di bursa efek bagi saham perusahaan publik atau estimasi harga untuk perusahaan yang tidak memiliki saham. Dalam bursa saham, angka ini berubah setiap hari sebagai respon terhadap hasil aktual atau yang diantisipasi dan sentimen pasar secara keseluruhan atau sektoral sebagaimana tercermin dalam indeks bursa saham. Hal itu juga menunjukkan bahwa tujuan utama manajemen adalah menjamin harga sebaik mungkin dalam kondisi apapun.

\section{Hipotesis}

Hipotesis yang diajukan dalam penelitian ini adalah sebagai berikut:

1. Diduga pertumbuhan ekonomi dan inflasi secara simultan berpengaruh terhadap terhadap harga saham perusahaan properti yang tercatat di Bursa Efek Indonesia.

2. Diduga pertumbuhan ekonomi dan inflasi secara parsial berpengaruh terhadap terhadap harga saham perusahaan properti yang tercatat di Bursa Efek Indonesia.

3. Diduga inflasi mempunyai pengaruh dominan terhadap terhadap harga saham perusahaan properti yang tercatat di Bursa Efek Indonesia

\section{METODE PENELITIAN}

\section{Jenis Penelitian dan Gambaran Obyek Penelitian}

Jenis penelitian yang dilakukan adalah penelitian kuantitatif. Pendekatan penelitian kuantitatif dapat diartikan sebagai metode penelitian yang berlandaskan pada filsafat positivisme, digunakan untuk meneliti pada populasi atau sampel tertentu, teknik pengambilan sampel pada umumnya dilakukan secara random, pengumpulan data menggunakan instrumen penelitian, analisis data bersifat statistik/kuantitatif dengan tujuanuntuk menguji hipotesis yang ditetapkan (Sugiyono, 2011:8).

Gambaran dari populasi (objek) penelitian ini adalah semua perusahaan properti yang terdaftar di Bursa Efek Indonesia.

\section{Sampel Penelitian}

Pengambilan sampel dalam penelitian ini dilakukan dengan metode purposive sampling dengan tujuan untuk mendapatkan sampel yang representatif sesuai dengan kriteria:

1. Perusahaan Real Estate and Property yang mengeluarkan laporan keuangan berturut-turut 2011-2015.

2. Perusahaan Real Estate and Property yang dijadikan sampel memiliki 
ekuitas positif dan laba positif berturut-turut 2011-2015.

3. Perusahaan yang memiliki harga saham aktif berturut-turut 2011-2015.

Berdasarkan kriteria tersebut, maka jumlah perusahaan yang terpilih jadi sampel penelitian adalah sebanyak 8 perusahaan. Sehingga jumlah observasi dalam penelitian ini adalah 5 tahun observasi x 8 sampel adalah 40 sampel observasi.

\section{Teknik Analisa Data}

Teknik analisis data dalam penelitian ini adalah sebagai berikut:

\section{Analisis Regresi Linier Berganda}

Analisis regresi linier berganda digunakan untuk mengukur ada atau tidaknya pengaruh antara pertumbuhan ekonomi (X1), dan inflasi (X2) sebagai variabel independent (bebas) terhadap harga saham (Y) sebagai variabel dependent (terikat). Rumus regresi linier berganda menurut Sugiyono (2011:192) adalah sebagai berikut: $\mathrm{Y}=\mathrm{a}+\mathrm{b} 1 \mathrm{X} 1+\mathrm{b} 2 \mathrm{X} 2$

Keterangan: Y

: Variabel terikat harga saham

A : Konstanta

b1,.. b2 : Koefisien regresi variabel bebas 1 sampai 2

X1 : Variabel pertumbuhan ekonomi

X2 : Variabel bebas inflasi

\section{Uji Asumsi Klasik}

Uji melihat layak atau tidaknya model regresi yang digunakan untuk memprediksi variabel terikat berdasarkan masukan variabel bebasnya, maka model regresi harus terbebas dari beberapa asumsi

\section{PEMBAHASAN}

\section{Analisis Regresi Linear Berganda}

Regresi linier berganda merupakan suatu persamaan yang menggambarkan hubungan antara dua atau lebih variabel bebas dengan satu variabel terikat. Regresi linier berganda diterapkan pada penelitian ini untuk mengetahui apakah terdapat pengaruh antara variabel bebas pertumbuhan ekonomi, dan inflasi terhadap variabel terikat harga saham, serta mengetahui besar pengaruhnya. Dari hasil pengolahan data dengan menggunakan Program SPSS diperoleh hasil sebagai berikut:

\begin{tabular}{|c|c|c|c|c|c|c|}
\hline \multicolumn{7}{|c|}{ Coefficients $^{\mathrm{a}}$} \\
\hline \multirow{2}{*}{\multicolumn{2}{|c|}{ Model }} & \multicolumn{2}{|c|}{ Unstandardized Coefficients } & \multirow{2}{*}{\begin{tabular}{|l} 
Standardized \\
Coefficients \\
Beta \\
\end{tabular}} & \multirow[t]{2}{*}{$\mathrm{t}$} & \multirow[t]{2}{*}{ Sig. } \\
\hline & & B & Std. Error & & & \\
\hline \multirow{3}{*}{1} & (Constant) & 549.525 & 158.681 & & 3.463 & .001 \\
\hline & $\mathrm{x} 1$ & -.281 & .332 & -.119 & -.847 & .402 \\
\hline & $\mathrm{x} 2$ & 8.601 & 2.438 & .497 & 3.528 & .001 \\
\hline
\end{tabular}

a. Dependent Variable: y 1 


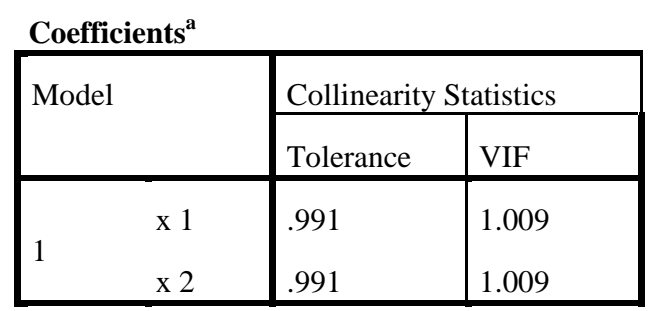

Tabel tersebut menunjukkan persamaan regresi yang dapat menjelaskan ada atautidaknya hubungan antara variabel bebas dengan variabel terikat serta dapat menginformasikan besarnya pengaruh variabel bebas terhadap variabel terikat. Dari tabel diperoleh model regresi linier berganda sebagai berikut :

$\mathrm{Y}=549.525-.281 \mathrm{X} 1-8.601 \mathrm{X} 2$

Berdasarkan model regresi di atas dapat dijelaskan bahwa:

1. Nilai a sebesar 549.525

Menunjukkan bahwa jika semua variabel bebas sama dengan nol maka besarnya harga saham akan konstan yaitu sebesar 549.525

2. Nilai b1 sebesar -.281

Menunjukkan bahwa jika pertumbuhan ekonomi (X1) meningkat satu satuan maka akan menurunkan harga saham sebesar -.281 satuan dengan asumsi variabel bebas yang lain konstan.

3. Nilai b2 sebesar 8.601

Menunjukkan bahwa jika inflasi (X2) meningkat satu satuan maka akan menurunkan harga saham sebesar 8.601satuan dengan asumsi variabel bebas yang lain konstan.

\section{Uji Asumsi Klasik}

Persamaan regresi yang baik harus bersifat BLUE (Best Linear Unbiased Estimator), artinya pengambilan keputusan melalui uji $\mathrm{F}$ dan uji $\mathrm{t}$ tidak boleh bias. Untuk menghasilkan keputusan yang BLUE tersebut maka harus dipenuhi beberapa asumsi klasik sebagai berikut:

\section{Uji Normalitas}

Uji normalitas digunakan untuk menguji apakah dalam model regresi variabel terikat dan variabel bebas keduanya mempunyai distribusi normal atau tidak. Modal regresi yang baik adalah memiliki distribusi data normal atau mendekati normal (Santoso, 2002:212). Untuk mendeteksi normalitas adalah dengan melihat penyebaran data/titik pada sumbu diagonal dari grafik, dasar pengambilan keputusan adalah:

a. Jika data menyebar disekitar garis diagonal dan mengikuti arah garis diagonal atau, maka model regresi memenuhi asumsi normalitas.

b. Jika data menyebar jauh garis diagonal dan/atau tidak mengikuti arah garis diagonal, maka model regresi tidak memenuhi asumsi normalitas 


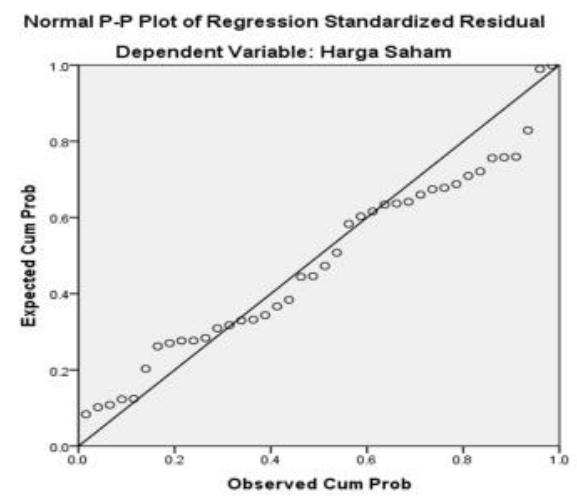

Dari grafik di atas diketahui bahwa titik-titik menyebar di sekitar garis diagonal. Jadi dapat disimpulkan bahwa model regresi layak dipakai karena memenuhi asumsi normalitas. Dimana uji ini dihitung dengan menggunakan alat bantu ukur program SPSS.

\section{Analisis Autokorelasi}

Uji autokorelasi dimaksudkan untuk mengetahui apakah dalam model regresi linear berganda ada korelasi antara kesalahan pengganggu pada periode $\mathrm{t}$ dengan kesalahan pada periode t-1 (sebelumnya). Jika terjadi korelasi, maka diidentifikasi terjadi masalah Autokorelasi. Regresi yang baik adalah regresi yang tidak terjadi Autokorelasi didalamnya.

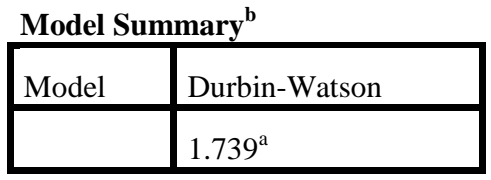

Untuk mendeteksi autokorelasi dapat dilakukan dengan uji Durbin Watson (DW) dengan ketentuan sebagai berikut:

a. 1,65 < DW $<2,35$ maka tidak ada autokorelasi.

b. $1,21<\mathrm{DW}<1,65$ atau $2,35<\mathrm{DW}<2,79$ maka tidak dapat disimpulkan

c. DW $<1,21$ atau DW $>2,79$ maka terjadi autokorelasi.

Berdasarkan tabel di atas diketahui bahwa model regresi yang terbentuk tidak terjadi Autokorelasi karena mempunyai angka Durbin Watson di antara 1,65 < DW< 2,35 sebesar yaitu 2,018.

\section{Uji Multikolinearitas}

Uji multikolinearitas dimaksudkan untuk mengidentifikasi hubungan antar variabel independen (bebas). Regresi yang baik adalah regresi yang variabel bebasnya tidak memiliki hubungan yang erat atau dengan kata lain tidak terjadi multikolinearitas antar variabel independennya. Ketentuan dalam pengujian ini adalah:

a. Jika nilai tolerance $<0,10$ dan VIF $>10$, maka terdapat korelasi yang terlalu besar di antara salah satu variabel bebas dengan variabel-variabel bebas yang lain (terjadi multikolinearitas).

b. Jika nilai tolerance $>0,10$ dan $\mathrm{VIF}<10$, maka tidak terjadi multikolinearitas. 
Dari hasil pengolahan data dengan program SPSS diperoleh hasil sebagai berikut:

\begin{tabular}{|c|c|c|c|}
\hline \multicolumn{4}{|c|}{ Coefficient Correlations $^{\mathrm{a}}$} \\
\hline Model & & x 2 & $\mathrm{x} 1$ \\
\hline \multirow{2}{*}{ Correlations } & x 2 & 1.000 & .092 \\
\hline & $\mathrm{x} 1$ & .092 & 1.000 \\
\hline \multirow{2}{*}{ Covariances } & $\mathrm{x} 2$ & 5.943 & .075 \\
\hline & $\mathrm{x} 1$ & .075 & .110 \\
\hline
\end{tabular}

a. Dependent Variable: y 1

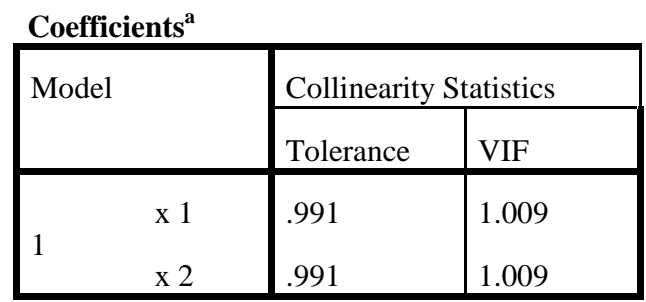

a. Dependent Variable: y 1

Dari 2 variabel bebas yang ada diketahui memiliki nilai tolerance $>0,1$ dan VIF $<10$ maka penelitian ini bebas dari Multikolinearitas.

\section{Uji Heteroskedastisitas}

Uji terhadap adanya Heteroskedastisitas adalah bertujuan untuk mengetahui apakah dalam sebuah model regresi terjadi ketidaksamaan varian residual dari pengamatan satu ke pengamatan yang lain. Jika varians dari pengamatan yang satu ke pengamatan yang lain tetap, maka ini disebut Homoskesdastisitas. Model regresi yang baik adalah model regresi yang tidak terjadi Heteroskedastisitas. Santoso (2002:210) mengatakan bahwa jika sebaran titik-titik berada di atas dan di bawah angka 0 pada sumbu Y dan tidak membentuk pola yang jelas, maka tidak terjadi Heteroskedastisitas. 


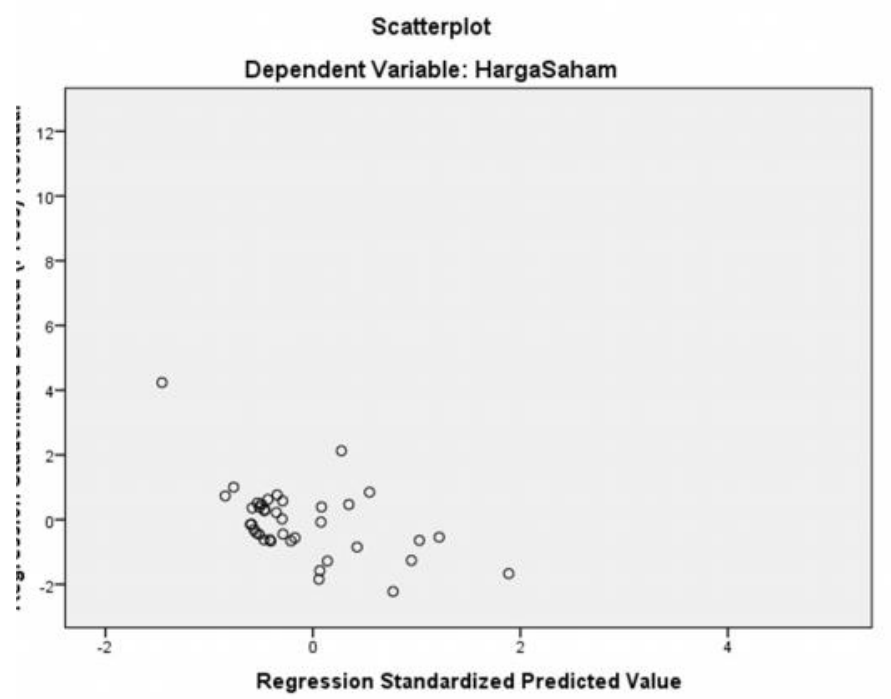

Dari grafik di atas diketahui bahwa titik-titik data tersebar di daerah antara $0-\mathrm{Y}$ dan tidak membentuk pola tertentu, maka model regresi yang terbentuk diidentifikasi tidak terjadi Heteroskedastisitas. Karena data yang diolah sudah tidak mengandung Heteroskedastisitas, maka persamaan regresi linear berganda yang diperoleh dapat dipergunakan untuk penelitian.

\section{Pengujian Pengaruh Simultan dengan Uji F}

Uji signifikansi model dengan uji $\mathrm{F}$ digunakan untuk mengetahui apakah model regresi linier berganda yang telah didapatkan telah signifikan (telah sesuai untuk menggambarkan pengaruh simultan variabel bebas terhadap variabel terikat). Uji signifikansi model ini dapat dilihat pada nilai $\mathrm{F}$ hitung yang telah diperoleh dari program SPSS sebagai berikut:

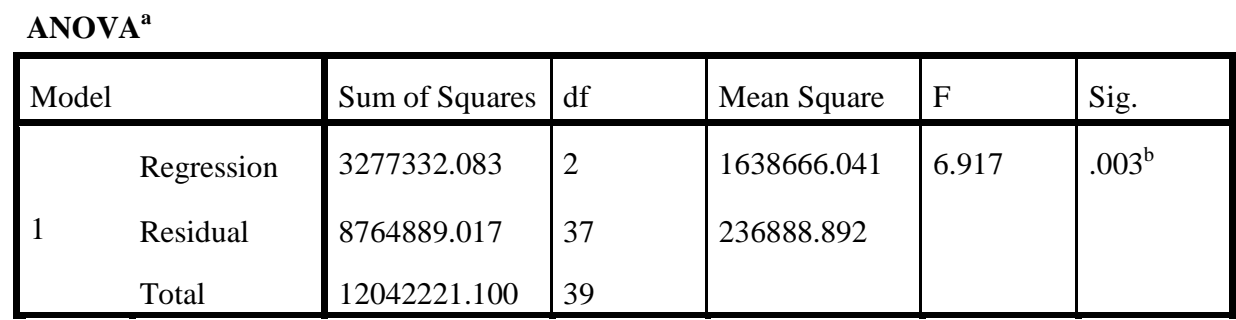

a. Dependent Variable: y 1

b. Predictors: (Constant), x 2, x 1

Untuk mengetahui variabel-variabel bebas berpengaruh secara simultan (bersama) terhadap variabel terikat digunakan uji $\mathrm{F}$ dengan tingkat signifikansi $\alpha=0,05$. Jika hasil statistik $\mathrm{F}$ pada taraf signifikansi $\leq 0,05$ berarti variabel-variabel bebas mempunyai pengaruh yang signifikan secara simultan terhadap variabel terikat dan sebaliknya. Karena nilai sig $<0,05$ yaitu $0,003<0,05$, sehingga dapat diambil kesimpulan bahwa pertumbuhan ekonomi dan inflasi secara simultan berpengaruh terhadap harga saham. Hasil penelitian ini berarti mendukung hipotesis bahwa pertumbuhan ekonomi dan inflasi secara simultan mempunyai pengaruh terhadap harga saham. 


\section{Analisis Pengaruh Parsial dengan Uji t}

Uji parsial (uji t) digunakan untuk mengetahui apakah model persamaan regresi telah signifikan untuk digunakan mengukur pengaruh secara parsial variabel bebas pertumbuhan ekonomi dan inflasi terhadap harga saham. Dari hasil pengolahan data dengan menggunakan Program SPSS diperoleh hasil output t hitung sebagai berikut:

\begin{tabular}{|c|c|c|c|c|c|c|}
\hline \multirow{2}{*}{\multicolumn{2}{|c|}{ Model }} & \multicolumn{2}{|c|}{ Unstandardized Coefficients } & \multirow{2}{*}{$\begin{array}{l}\text { Standardized } \\
\text { Coefficients } \\
\text { Beta } \\
\end{array}$} & \multirow[t]{2}{*}{$\mathrm{T}$} & \multirow[t]{2}{*}{ Sig. } \\
\hline & & $\mathrm{B}$ & Std. Error & & & \\
\hline \multirow{3}{*}{1} & (Constant) & 549.525 & 158.681 & & 3.463 & .001 \\
\hline & $\mathrm{x} 1$ & -.281 & .332 & -.119 & -.847 & .402 \\
\hline & $\mathrm{x} 2$ & 8.601 & 2.438 & .497 & 3.528 & .001 \\
\hline
\end{tabular}

a. Dependent Variable: y 1

Prosedur pengujian menggunakan uji t dengan tingkat signifikansi 0,05.

1. Uji parsial antara variabel bebas pertumbuhan ekonomi (X1) terhadap harga saham (Y), dengan nilai sig $=0,402$ Karena nilai sig 0,402 >0,05 hal ini berarti bahwa variabel bebas Pertumbuhan ekonomi secara parsial tidak berpengaruh signifikan terhadap harga saham.

2. Uji parsial antara variabel bebas inflasi (X2) terhadap harga saham (Y), dengan nilai sig $=0,001$ Karena nilai sig $0,001<0,05$ hal ini berarti bahwa variabel bebas suku bunga secara parsial berpengaruh signifikan terhadap harga saham.

\section{Interpretasi}

Berdasarkan uji $\mathrm{F}$ diketahui bahwa pertumbuhan ekonomi dan inflasi secara simultan berpengaruh terhadap harga saham. Hasil penelitian ini berarti mendukung hipotesis yang telah ditetapkan yaitu "Diduga pertumbuhan ekonomi, dan inflasi secara simultan berpengaruh terhadap harga saham." Adanya pengaruh simultan ini menunjukkan bahwa faktor-faktor makroekonomi secara bersama-sama turut mempengaruhi besarnya harga saham. Berdasarkan hasil uji t dapat diketahui bahwa pertumbuhan ekonomi secara parsial tidak berpengaruh terhadap hatga saham. Hasil penelitian ini berarti tidak mendukung hipotesis yang telah ditetapkan yaitu "Diduga pertumbuhan ekonomi secara parsial mempunyai pengaruh terhadap harga saham." Tidak adanya pengaruh pertumbuhan ekonomi terhadap harga saham ini lebih disebabkan karena perusahaan property semakin di butuhkan kedepanya sehingga harga saham kian meningkat dan para calon investor dari dalam negri maupun luar negri banyak mengincar saham di dunia property dengan tidak terlalu memikirkan pertumbuhan ekonomi .

Berdasarkan hasil uji t diketahui bahwa inflasi secara parsial berpengaruh terhadap harga saham. Hasil penelitian ini berarti mendukung hipotesis yang telah ditetapkan yaitu "Diduga inflasi secara parsial mempunyai pengaruh terhadap harga saham." Adanya pengaruh inflasi terhadap harga saham ini lebih disebabkan karena jika suku bunga tinggi maka masyarakat cenderung untuk menabung, sedangkan jika suku bunga rendah maka masyarakat lebih tertarik menginvestasikan dananya pada sektor riil termasuk sektor peroperti. Sehingga dapat disimpulkan jika suku bunga menurun, maka harga saham properti akan meningkat. Dari hasil uji t diketahui bahwa inflasi secara 
parsial tidak berpengaruh terhadap harga saham. Hasil penelitian ini berarti mendukung hipotesis yang telah ditetapkan yaitu "Diduga inflasi secara parsial mempunyai pengaruh terhadap harga saham." Adanya pengaruh inflasi terhadap harga saham ini menunjukkan bahwa adanya inflasi tak membuat bisnis properti terpengaruh. Inflasi yang terjadi sepanjang tahun 2011-2015 masih dapat mendorong perekonomian lebih baik, yaitu meningkatkan pendapatan nasional dan membuat orang bergairah untuk bekerja, menabung, dan mengadakan investasi. Dari hasil penelitian dapat diketahui bahwa pengaruh dominan terhadap harga saham ditunjukkan oleh variabel suku bunga. Hasil penelitian ini berarti mendukung hipotesis ketiga bahwa suku bunga secara parsial berpengaruh dominan terhadap harga saham.

\section{KESIMPULAN}

Berdasarkan hasil penelitian dapat diambil beberapa simpulan yang nantinya dapat digunakan sebagai bahan pertimbangan, yaitu:

1. Berdasarkan hasil uji $\mathrm{F}$ diketahui bahwa pertumbuhan ekonomi dan inflasi secara simultan berpengaruh terhadap harga saham. Hasil penelitian ini berarti mendukung hipotesis bahwa pertumbuhan ekonomi dan inflasi secara simultan mempunyai pengaruh terhadap harga saham.

2. Berdasarkan hasil uji $\mathrm{t}$ diketahui bahwa inflasi secara parsial berpengaruh terhadap harga saham. Hasil penelitian ini berarti mendukung hipotesis yang telah ditetapkan yaitu inflasi secara parsial berpengaruh terhadap harga saham.

3. Sedangkan dari hasil uji t juga diketahui bahwa pertumbuhan ekonomi secara parsial tidak berpengaruh terhadap harga saham. Hasil penelitian ini berarti tidak mendukung hipotesis yang telah ditetapkan yaitu bahwa pertumbuhan ekonomi secara parsial berpengaruh terhadap harga saham.

4. Dari hasil penelitian dapat diketahui bahwa pengaruh dominan terhadap harga saham ditunjukkan oleh variabel inflasi. Hasil penelitian ini berarti mendukung hipotesis bahwa inflasi secara parsial berpengaruh dominan terhadap harga saham.

\section{SARAN}

Berdasarkan hasil penelitian dan simpulan, maka saran-saran yang dapat diajukan yang berkaitan dengan penelitian ini adalah sebagai berikut:

1. Para investor yang ingin menginvestasikan dananya pada perusahaan properti sebaiknya memperhatikan hasil penelitian ini karena hasil penelitian ini menunjukkan bahwa pertumbuhan ekonomi dan inflasi berpengaruh terhadap harga saham.

2. Disarankan kepada peneliti-peneliti selanjutnya untuk melakukan penelitian serupa dengan batasan-batasan tertentu yang lebih bervariatif agar memperoleh kesimpulan yang lebih baik daripada penelitian ini.

\section{DAFTAR PUSTAKA}

Adiwarman, K. 2008. Mengantisipasi Dampak Krisis Keuangan Global. Impresario BRI. Jakarta.

Depprin RI. 2008. Tanya Jawab Memahami Krisis Keuangan Global, Bagaimana PemerintahMengatasinya.http://www.setneg.go.id/image/stories/kepmen/kontrib utor/buku_2- krisis_finansial_global_tanya_jawab. Diakses tanggal 22 Juli 2013. 
Hakim, A. 2010. Ekonomi Pembangunan. Ekonisia. Yogyakarta.

Kashmir. 2008. Bank dan Lembaga Keuangan Lainnya. Rajawali Pers. Jakarta.

Khalwaty, T. 2010. Inflasi dan Solusinya. PT Gramedia Pustaka Utama. Jakarta.

Mishkin, S.F. 2008. Ekonomi Uang, Perbankan, dan Pasar Keuangan. Buku 1.

Edisi ke-8. Salemba Empat. Jakarta.

Nopirin. 2009. Ekonomi Moneter. Edisi Satu. Cetakan ke 12. Penerbit BPFE. Jakarta.

Santoso, S. 2002. SPSS Versi 10 : Mengolah Data Statistik Secara Profesional. PT. Elex Media Komputindo. Jakarta.

Sugiyono. 2011. Metode Penelitian Kuantitatif, Kualitatif Dan R\&D. Cetakan ke-13. Penerbit Alfabeta. Bandung.

Sukirno, S. 2012. Makroekonomi. Teori Pengantar. Edisi Ketiga. Cetakan ke 21. PT. Raja Grafindo Persada. Jakarta.

Sunyoto, D. 2011. Analisis Regresi dan Uji Hipotesis. Penerbit CAPS. Yogyakarta.

Tandelilin, E. 2010. Analisis Investasi dan Manajemen Portofolio. Edisi Pertama. Cetakan Pertama. BPFE. Yogyakarta.

www.tempointeraktif.com. Pasar Perawatan Pesawat Masih Dikuasai Asing Kamis, 26 Juni 2008. Diakses tanggal 22 Mei 2013. 